\title{
HAEMORRHAGIC DIATHESIS DUE TO DEFICIENCY OF FACTOR VII
}

\author{
BY \\ J. S. JENKINS \\ From the Department of Clinical Pathology, St. Bartholomew's Hospital, London
}

(RECEIVED FOR PUBlicATION JULY 11, 1953)

Of recent years it has become apparent that Quick's one-stage prothrombin time, although a most useful routine laboratory test, does not specifically measure plasma prothrombin.

Quick himself (1947) recognized that deficiency of his labile factor (Factor V) caused lengthening of the prothrombin time, and Owren (1947) reported the first case of congenital deficiency of Factor $\mathrm{V}$ causing a haemorrhagic state which he termed " parahaemophilia."

It is now known that a prolonged prothrombin time may result from lack of another factor which normally develops in serum during coagulation, and has been named by various workers "serum prothrombin conversion accelerator (Alexander), "convertin" (Owren), and Factor VII (Koller, Loeliger, and Duckert, 1951).

Only two undoubted cases of congenital deficiency of this factor have so far been described, the first by Alexander, Goldstein, Landwehr, and Cook (1951), and another by Owren (1952). The following case appears to be the third example.

\section{Case Report}

Mr. R.H., aged 49, was admitted to hospital in November, 1952, complaining of blood in the stools. At the age of 5 he had suffered from epistaxes and haemarthroses of the knee joints. Further epistaxes occurred during school life, and slight trauma caused haemarthroses of the ankle joints at the age of 22 . Haemorrhages, mostly epistaxes, continued to occur and in 1946 he began to notice occasional blood in the stools. In April, 1952, rectal bleeding recurred and continued intermittently until admission to hospital. Family history revealed no definite evidence of haemorrhagic disease in his immediate relations.

On admission he was pale with a temperature of $99^{\circ} \mathrm{F}$., pulse 90 . There was full movement of all joints. The stools contained bright red blood. On investigation $\mathrm{Hb}$ was $48 \%(7.1 \mathrm{~g}$. per $100 \mathrm{ml}$.), red cells 4.05 million and white cells 6,400 per c.mm., with a normal differential count. The blood sedimentation rate was $3 \mathrm{~mm}$. per hour, the platelets 521,000 per c.mm., bleeding time (Duke) 4 min., and plasma fibrinogen $250 \mathrm{mg}$. per $100 \mathrm{ml}$. A barium enema was normal on two occasions, and proctoscopy and sigmoidoscopy revealed no local lesion. Vitamin $K$ in the form of "synkavit" was given in the dose of $100 \mathrm{mg}$. daily for 17 days by intramuscular injection without effect. Blood transfusions raised the haemoglobin to $94 \%$, and the bleeding gradually declined in severity. He remained well with a haemoglobin value of $92 \%$ when seen six weeks after leaving hospital.

\section{Investigation of the Coagulation Defect}

Methods.-One-stage prothrombin times were carried out by Quick's method using "difco" rabbit brain thromboplastin. Two-stage prothrombin estimations were carried out by Ware and Seegers' method (1949), using "difco" two-stage reagent, except that Factor $\mathrm{V}$ was supplied by $\mathrm{Ca}_{3}\left(\mathrm{PO}_{4}\right)_{2}$-treated plasma and Factor VII by prothrombin-free normal serum both in 1 in 150 dilution.

Prothrombin consumption was determined by the one-stage method of Stefanini and Crosby (1950) modified by the addition of Factor VII when estimating the plasma and serum prothrombin times. Factor $\mathrm{V}$ was investigated as shown below.

Plasma containing Factor V, but free from prothrombin and Factor VII, was obtained by treatment with an equal quantity of $0.008 \mathrm{M}$-tricalcium phosphate suspension, $\mathrm{Ca}_{3}\left(\mathrm{PO}_{4}\right)_{2}$.

The adsorbed prothrombin and Factor VII was obtained in solution by eluting the precipitate with $0.2 \mathrm{M}$-sodium citrate in a volume one-tenth of the original plasma.

Serum was rendered free from Factor VII by similar treatment with $\mathrm{Ca}_{3}\left(\mathrm{PO}_{4}\right)_{2}$ and the adsorbed Factor VII was obtained in solution by elution of the precipitate with sodium citrate in a volume one-tenth of the original serum.

Coagulation Time.-Determined by the Lee and White method this was five to eight minutes (normal five to ten minutes).

One-stage Prothrombin Times.-These ranged from 39 secs. to 70 secs. (normal $15-17$ secs). 
Two-stage Prothrombin Test.-Prothrombin by this method was $89 \%$ of normal, the patient's plasma containing 144 units and the normal 165 units after two minutes' incubation with supplementary Factor V and Factor VII. If Factor VII was omitted, the value for normal plasma remained the same but the patient's plasma showed a significant delay in thrombin formation and the peak yield was reduced to 127 units after seven minutes' incubation.

Factor V.-Factor V (labile factor) was shown to be normal by two methods: (1) Stored normal plasma gave a prothrombin time of 40 secs. (normal 17) and stored normal plasma plus the patient's plasma in equal parts gave a prothrombin time of 16 secs.; (2) $90 \%$ of normal $\mathrm{Ca}_{3}\left(\mathrm{PO}_{4}\right)_{2}$ plasma plus $10 \%$ of normal prothrombin plus Factor VII gave a prothrombin time 16 secs., $90 \%$ of patient's $\mathrm{Ca}_{3}\left(\mathrm{PO}_{4}\right)_{2}$ plasma plus $10 \%$ of normal prothrombin plus Factor VII gave 16 secs., and $90 \%$ of normal $\mathrm{Ca}_{3}\left(\mathrm{PO}_{4}\right)_{2}$ plasma plus $10 \%$ of patient's prothrombin plus Factor VII gave 42 secs.

This experiment demonstrates that $\mathrm{Ca}_{3}\left(\mathrm{PO}_{4}\right)_{2}$ removes Factor VII from normal plasma but leaves Factor $\mathrm{V}$ intact.

Prothrombin Consumption Index.-This, after the addition of Factor VII, was 6\% (normal 1\%-15\%).

Factor VII.-Table I shows the effect of normal serum, normal plasma, and patient's serum on the prothrombin time when mixed in various proportions with the patient's plasma. Ten per cent. of normal serum completely corrected the prothrombin time and was approximately twice as effective as normal plasma. The patient's serum was relatively ineffective.

TABLE I

PLASMA MIXTURES (PARTS)

\begin{tabular}{c|c|c|c|c}
\hline $\begin{array}{c}\text { Patient's } \\
\text { Plasma }\end{array}$ & $\begin{array}{c}\text { Patient's } \\
\text { Serum }\end{array}$ & $\begin{array}{c}\text { Normal } \\
\text { Plasma }\end{array}$ & $\begin{array}{c}\text { Normal } \\
\text { Serum }\end{array}$ & $\begin{array}{c}\text { Prothrombin } \\
\text { Time (Sec.) }\end{array}$ \\
\hline 1 & & & 1 & 50 \\
9 & & 1 & 17 \\
9 & 1 & & 1 & 23 \\
9 & 1 & & 22 \\
19 & & & 42 \\
\hline
\end{tabular}

Prothrombin times were carried out on $0.1 \mathrm{ml}$. of mixture in each case. Prothrombin time of normal control plasma, 17 secs.

TABLE II

\begin{tabular}{|c|c|c|c|c|c|c|}
\hline $\begin{array}{c}\text { Patient's } \\
\text { Plasma }\end{array}$ & $\begin{array}{c}\text { Patient's } \\
\text { Pro- } \\
\text { thrombin } \\
\text { Solution }\end{array}$ & $\begin{array}{l}\text { Factor } \\
\text { VII } \\
\text { from } \\
\text { Normal } \\
\text { Serum }\end{array}$ & $\begin{array}{c}\text { Factor } \\
\text { VII } \\
\text { from } \\
\text { Patient's } \\
\text { Serum }\end{array}$ & $\begin{array}{c}\text { Normal } \\
\mathrm{Ca}_{3}\left(\mathrm{PO}_{4}\right) \\
\text { Serum }\end{array}$ & $\begin{array}{c}\text { Normal } \\
\mathrm{Ca}_{3}\left(\mathrm{PO}_{4}\right)_{2} \\
\text { Plasma }\end{array}$ & $\mid \begin{array}{c}\text { Pro- } \\
\text { thrombin } \\
\text { Time } \\
\text { (Sec.) }\end{array}$ \\
\hline \multirow[t]{2}{*}{$\begin{array}{l}1 \\
1 \\
9\end{array}$} & & 1 & & 1 & & $\begin{array}{l}50 \\
70 \\
12\end{array}$ \\
\hline & $\begin{array}{l}1 \\
1 \\
1\end{array}$ & 1 & 1 & & $\begin{array}{l}9 \\
8 \\
8\end{array}$ & $\begin{array}{l}60 \\
13 \\
80\end{array}$ \\
\hline
\end{tabular}

Prothrombin times were carried out on $0.1 \mathrm{ml}$. of mixture in each case. Prothrombin time of normal control plasma, 17 secs.
Table II shows the effect of preparations of Facto VII from normal serum and the patient's serum con $\frac{D}{4}$ centrated in a volume one-tenth of the original serum? These preparations were tested on the patient's plasm: and on a solution of the patient's prothrombin cons centrated in a volume one-tenth of the original plasma

Again, normal Factor VII was very potent in accelerating the prothrombin time whereas the patient's Factor VII was deficient.

Normal serum treated with $\mathrm{Ca}_{3}\left(\mathrm{PO}_{4}\right)_{2}$ was devoidof Factor VII activity.

"Tromexan" Plasma.-The plasma from a case of coronary thrombosis receiving "tromexan" had little effect: $90 \%$ of patient's plasma plus $10 \%$ of "tro" mexan " plasma gave a prothrombin time of 43 secsin and $90 \%$ of patient's plasma plus $10 \%$ of normalo plasma gave a prothrombin time of 22 secs. (The prothrombin time of the patient's plasma was 55 secs.,, of "tromexan" plasma 33 secs., and of the normati plasma 16 secs.).

Blood Transfusion.-A slight transitory effect wa observed: November 25 , prothrombin time 46 secs., and 24 hours after $2 \frac{1}{2}$ pints stored blood, 36 secs. $\overrightarrow{0}$ December 2, prothrombin time 50 secs., and 12 hours after 3 pints fresh blood, 33 secs. ; December 9, pro:thrombin time 50 secs., during transfusion of fresto blood (after $1 \frac{1}{2}$ pints) 28 secs., and 18 hours after the transfusion, 50 secs.

\section{Discussion}

Factor VII (Koller et al., 1951) develops in normal serum during coagulation from a precurso 5 in the plasma, and appears to be identical with the "serum prothrombin conversion accelerator" of Alexander and the " convertin " of Owren. Unlike. Factor V, it is adsorbed by inorganic precipitates and can be eluted by sodium citrate. It is con? siderably reduced by administration of "tro". mexan " or "dicoumarol," and, in fact, the lengtho ened "prothrombin time" in the first few days of treatment with these drugs is largely due to reducs tion of Factor VII (Koller et al., 1952). The haemorrhagic diathesis of the case here reportec. appears to be due to Factor VII deficiency, probs ably congenital in origin, since haemorrhages had occurred from early childhood. Plasma prop thrombin was shown to be normal by the two-stage method in spite of a grossly increased "pro thrombin" time. This could be completely cof rected in vitro by the addition of normal serumb and to a less extent by normal plasma. The serum factor had the properties of Factor VII and the patient's serum was shown to be deficient in thio respect. "Tromexan" plasma, being deficient i Factor VII, also had little effect.

The effect of blood transfusions, which were given mainly to correct the anaemia, had a slight 
but transitory effect on the prothrombin time. From the in vitro experiments the transfusion of normal serum would seem to have the greater promise of correcting the coagulation defect, but in the case of Alexander et al. (1951), where this was done, the effect was again of only short duration. Although only two previous cases of this condition have been recorded, it seems probable that some cases of so-called "idiopathic hypoprothrombinaemia" where only one-stage prothrombin times were performed, were examples of Factor VII deficiency.

Recently, Biggs, Douglas, Macfarlane, Dacie, Pitney, Merskey, and O'Brien (1952) have reported a series of cases of a haemorrhagic state closely resembling haemophilia, which they have termed "Christmas disease," due to deficiency of a serum factor having many of the properties of Factor VII. This disease, however, is distinguishable from Factor VII deficiency by a normal prothrombin time and impaired prothrombin consumption.

\section{Summary}

A case of a haemorrhagic diathesis present from early childhood is reported.

The prothrombin level was normal in spite of a greatly prolonged Quick's prothrombin time.

The coagulation defect could be completely corrected in vitro by serum containing Factor VII.

Treatment by blood transfusion and serum transfusion is discussed.

I wish to thank Dr. R. Bodley Scott for permission to publish this report.

\section{REFERENCES}

Alexander, B., Goldstein, R., Landwehr, G., and Cook, C. D. (1951). J. clin. Invest., 30, 596.

Biggs, R., Douglas, A. S., Macfarlane, R. G., Dacie, J. V., Pitney, W. R.. Merskey, C., and O'Brien, J. R. (1952). Brit. med. J., 2, 1378.

Koller, F., Loeliger, A., and Duckert, F. (1951). Acta Haemat., 6, 1. - (1952). Rev. Hématol., 7, 156.

Owren, P. A. (1947). Lancet, 1, 446

(1952). Blood Clotting and Allied Problems, Fifth Conference of Josiah Macy Foundation, New York, p. 101.

Quick, A. J. (1947). Lancet, 2, 379.

Stefanini, M., and Crosby, W. H. (1950). Blood, 5, 964.

Ware, A. G., and Seegers, W. H. (1949). Amer. J. clin. Path., 19, 471. 